\title{
Pd(II) Coordination Sphere Engineering: Pyridine Cages, Quinoline Bowls, and Heteroleptic Pills Binding One or Two Fullerenes
}

\author{
Bin Chen, ${ }^{\dagger}$ Julian J. Holstein, ${ }^{\dagger}$ Shinnosuke Horiuchi, ${ }^{\dagger, \ddagger}$ Wolf G. Hiller, ${ }^{\dagger}$ and Guido H. Clever ${ }^{*}{ }^{\dagger}$ (৫) \\ ${ }^{\dagger}$ Faculty of Chemistry and Chemical Biology, TU Dortmund University, Otto-Hahn Straße 6, 44227 Dortmund, Germany \\ ${ }^{\ddagger}$ Division of Chemistry and Materials Science, Graduate School of Engineering, Nagasaki University, Bunkyo-machi, Nagasaki \\ 852-8521, Japan
}

Supporting Information

\begin{abstract}
Fullerenes and their derivatives are of tremendous technological relevance. Synthetic access and application are still hampered by tedious purification protocols, peculiar solubility, and limited control over regioselective derivatization. We present a modular self-assembly system based on a new low-molecular-weight binding motif, appended by two palladium(II)-coordinating units of different steric demands, to either form a $\left[\mathrm{Pd}_{2} \mathbf{L}_{4}{ }_{4}{ }^{4+}\right.$ cage or an unprecedented $\left[\mathrm{Pd}_{2} \mathbf{L}_{3}{ }_{3}(\mathrm{MeCN})_{2}\right]^{4+}$ bowl (with $\mathbf{L}^{1}=$ pyridyl, $\mathbf{L}^{2}=$ quinolinyl donors). The former was used as a selective induced-fit receptor for $\mathrm{C}_{60}$. The latter, owing to its more open structure, also allows binding of $\mathrm{C}_{70}$ and fullerene derivatives. By exposing only a fraction of the bound guests' surface, the bowl acts as fullerene protecting group to control functionalization, as demonstrated by exclusive monoaddition of anthracene. In a hierarchical manner, sterically low-demanding dicarboxylates were found to bridge pairs of bowls into pill-shaped dimers, able to host two fullerenes. The hosts allow transferring bound fullerenes into a variety of organic solvents, extending the scope of possible derivatization and processing methodologies.
\end{abstract}

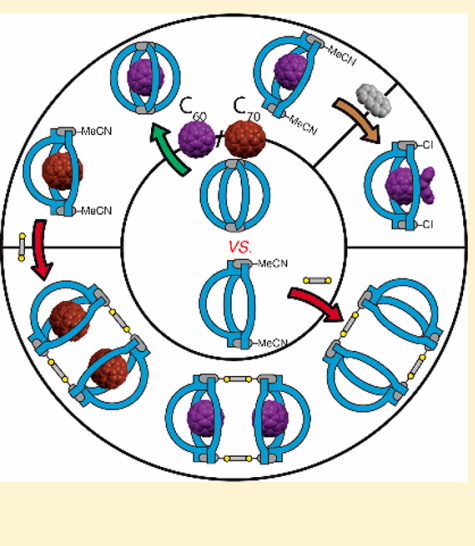

\section{INTRODUCTION}

As stable carbon allotropes, fullerenes feature curved, fully $\pi$ conjugated surfaces with unique electronic properties that render them highly versatile for application in functional materials. ${ }^{1}$ Established techniques for the separation of industrial fullerene mixtures are based on sublimation, crystallization, extraction, and chromatographic protocols. ${ }^{2}$ The scope of solution processing methods, e.g., for controlled derivatization, preparation of composite materials, surface deposition, and device fabrication, is still limited due to the small choice of suitable aromatic and halogenated solvents.

Within the field of supramolecular chemistry, large efforts have been devoted to the construction of fullerene receptors aimed at facilitating selective purification and derivatization methods. ${ }^{3}$ In this regard, covalent organic tweezers and macrocycles based on extended aromatic panels, such as calixarenes, porphyrins and extended tetrathiafulvalenes, fully conjugated belts, as well as curved architectures such as triptycenes, have been intensively studied. ${ }^{4}$ As most of these host compounds are the result of lengthy syntheses, selfassembled fullerene binders composed of much simpler building blocks have moved into focus, recently. Among those, metal-mediated rings and cages are notably versatile, owing to their modular composition and tunable cavity. Examples include Yoshizawa's anthracene-lined $\left[\mathrm{M}_{2} \mathrm{~L}_{4}\right]^{4+}$ cages, ${ }^{5}$ Nitschke's tetrahedral aromatic-paneled arrangement, ${ }^{6}$ cubic porphyrin boxes, ${ }^{3 a, 7}$ and Ribas' heteroleptic prismatic cage. $^{3 c, 8}$
Common to most previously reported metal-mediated fullerene receptors ${ }^{3 b}$ is their rather high molecular weight, as a result of maximizing the offered $\pi$-surface area. We were therefore interested in designing a new metallo-supramolecular receptor based on the well-studied $\left[\mathrm{Pd}_{2} \mathrm{~L}_{4}\right]^{4+}$ coordination cage motif, ${ }^{9}$ that is (1) of lower molecular weight than existing hosts, (2) straightforward to synthesize and derivatize, and (3) capable of discriminating different fullerenes and dissolving them in a range of organic solvents. On the basis of computeraided modeling, we further aimed at finding a perfect structural match between a curved binding motif, the connective metal complex, and the spherical $\mathrm{C}_{60}$ fullerene. Our design is based on a curved dibenzo-2.2.2-bicyclo-octane backbone reminiscent of triptycen $\mathrm{e}^{10}$ but lacking the third benzene ring that is not in touch with the fullerene guest (Figure 1a and Figure S117).

We introduced phthalimide-based joints to pyridines, that coordinate to $\mathrm{Pd}(\mathrm{II})$ cations, thereby bringing all four ligands into perfect relative distances to be able to encapsulate $\mathrm{C}_{60}$ fullerene. Indeed, the as-planned host performed excellently as a fullerene host, and initial concerns that a receptor containing eight phthalimide units would become too electron-deficient to bind $\mathrm{C}_{60}$ did not materialize. In addition, ligand derivatization with sterically more demanding quinoline donors yielded an unprecedented $\left[\mathrm{Pd}_{2} \mathrm{~L}_{3}^{2} \mathrm{X}_{2}\right]^{n+}$ bowl structure $\left(\mathrm{X}=\mathrm{CH}_{3} \mathrm{CN}\right.$ or $\mathrm{Cl}^{-}$), which allowed us to extend the guest scope to $\mathrm{C}_{70}$ and

Received: February 26, 2019

Published: May 8, 2019 


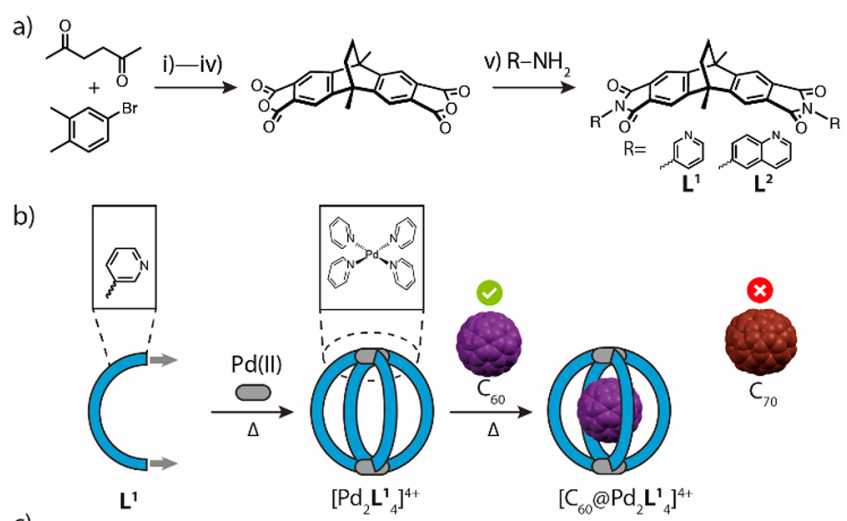

c)

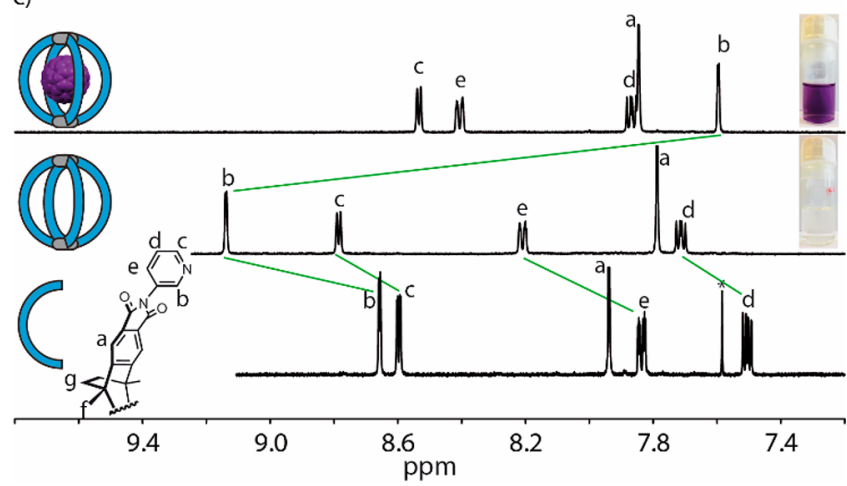

Figure 1. Ligand and cage synthesis. (a) Preparation of ligands $\mathbf{L}^{1}$ and $\mathbf{L}^{2}$ : (i) $\mathrm{Mg}$, THF; (ii) $\mathrm{AlCl}_{3}$, toluene; (iii) $\mathrm{KMnO}_{4}$, pyridine $/ \mathrm{H}_{2} \mathrm{O}$; (iv) $\mathrm{Ac}_{2} \mathrm{O}$; (v) for $\mathrm{L}^{1}$ : 3-aminopyridine, $165{ }^{\circ} \mathrm{C}, 10 \mathrm{~min}$; for $\mathrm{L}^{2}$ : 6aminoquinoline, $165{ }^{\circ} \mathrm{C}, 10 \mathrm{~min}$. (b) Ligand $\mathrm{L}^{1}$ assembles with $\mathrm{Pd}^{\mathrm{II}}$ cations to cage $\left[\mathrm{Pd}_{2} \mathrm{~L}_{4}\right]^{4+}$ capable of selectively binding $\mathrm{C}_{60}$. (c) ${ }^{1} \mathrm{H}$ NMR spectra $\left(600 \mathrm{MHz}, 298 \mathrm{~K}, \mathrm{CD}_{3} \mathrm{CN}\right)$ of Ligand $\mathrm{L}^{\mathrm{1}}(2.56 \mathrm{mM})$, cage $\left[\mathrm{Pd}_{2} \mathbf{L}_{4}{ }_{4}\right]^{4+}(0.64 \mathrm{mM})$, host-guest complex $\left[\mathrm{C}_{60} @ \mathrm{Pd}_{2} \mathbf{L}_{4}{ }_{4}\right]^{4+}$ $(0.64 \mathrm{mM})$ obtained from mixing free cage $\left[\mathrm{Pd}_{2} \mathrm{~L}_{4}{ }^{1}\right]^{4+}$ with pure $\mathrm{C}_{60}$ at $70{ }^{\circ} \mathrm{C}$ (from bottom to top).

use it as a fullerene-protecting group in cycloaddition reactions with anthracene. The bowl's sterically congested coordination environment allows clean conversion into a heteroleptic assembly $^{11}$ via hierarchical reaction with bridging carboxylates, ${ }^{8 c, 12}$ thus yielding a pill-shaped dimer, capable of binding two fullerenes. ${ }^{13}$ All findings are supported by NMR and mass spectrometric results as well as single crystal X-ray structures of one ligand, both empty hosts, and three different host-guest complexes, achieved with a combination of cryogenic crystal handling, the use of highly brilliant synchrotron radiation, ${ }^{14}$ and advanced macromolecular refinement protocols.

\section{RESULTS AND DISCUSSION}

Ligand Synthesis, Cage Assembly, Fullerene Binding. Backbone dianhydride, depicted in Figure 1a, was prepared in four steps starting from 4-bromo-1,2-dimethylbenzene and 2,5hexanedione according to a reported procedure. ${ }^{15}$ Straightforward conversion into ligands $\mathbf{L}^{\mathbf{1}}$ and $\mathbf{L}^{2}$ was achieved by reaction with 3 -aminopyridine and 6-aminoquinoline, respectively. Likewise to other banana-shaped, bis-monodentate pyridyl ligands reported previously, heating a 2:1 mixture of $\mathbf{L}^{1}$ and $\left[\mathrm{Pd}(\mathrm{MeCN})_{4}\right]\left(\mathrm{BF}_{4}\right)_{2}$ in deuterated acetonitrile at 70 ${ }^{\circ} \mathrm{C}$ for $1 \mathrm{~d}$ resulted in the quantitative formation of cage $\left[\mathrm{Pd}_{2} \mathbf{L}_{4}\right]^{4+}$, unambiguously characterized by ${ }^{1} \mathrm{H}$ NMR spectroscopy (Figure $1 \mathrm{~b}$ and $\mathrm{c}$ ), mass spectrometry (Figure S8), and a single crystal X-ray structure (Figure $4 a$ ). The ${ }^{1} \mathrm{H}$ NMR spectrum reveals that the proton signals of the pyridine moieties undergo a downfield shift associated with metal complexation. Encapsulation of $\mathrm{C}_{60}$ and $\mathrm{C}_{70}$ were tested by stirring acetonitrile solutions of the cage over the solid fullerenes (usually adding an excess of finely ground material, while about 1.2 equiv were found to be sufficient). Intriguingly, $\left[\mathrm{Pd}_{2} \mathrm{~L}_{4}{ }_{4}\right]^{4+}$ is only able to encapsulate $\mathrm{C}_{60}$, but not $\mathrm{C}_{70}$, which we attribute to the good match in terms of shape (spherical $\mathrm{C}_{60}$ vs ellipsoidal $\left.\mathrm{C}_{70}\right)$ and size ( $572 \AA^{3}$ void space; Figure S114; vs $547 \AA^{3}$ van-der-Waals volume of $\mathrm{C}_{60}, 646 \AA^{3}$ of $\left.\mathrm{C}_{70}\right)^{16}$ for the tailor-made cavity. Upon absorbing $\mathrm{C}_{60}$ inside the cage, the ${ }^{1} \mathrm{H}$ NMR signal of inward-pointing proton $\mathrm{H}_{b}$ undergoes an upfield-shift of $1.54 \mathrm{ppm}$, along with a color change of the solution from colorless to purple (Figure 1c). Further indication of $\mathrm{C}_{60}$ binding was observed in the $\mathrm{UV}-$ vis and high-resolution ESI mass spectra (Figure S12 and S104). Upon binding $\mathrm{C}_{60}$, the acetonitrile solution of $\left[\mathrm{C}_{60} @ \mathrm{Pd}_{2} \mathbf{L}_{4}{ }_{4}\right]^{4+}$ showed a broad absorption band around $\lambda_{\max }=339 \mathrm{~nm}$. Besides acetonitrile, also other solvents such as acetone, nitromethane, and DMF could be used to dissolve the cage and the host-guest complex (Figure S81-S89).

Diffusion of isopropyl ether into the acetonitrile solution of $\left[\mathrm{C}_{60} @ \mathrm{Pd}_{2} \mathbf{L}_{4}{ }_{4}\right]\left(\mathrm{BF}_{4}\right)_{4}$ allowed us to grow single crystals in the form of red plates, suitable for synchrotron X-ray diffraction analysis. Three crystallographically independent host-guest complexes were found in the asymmetric unit, all showing the same $\mathrm{C}_{60}$-occupied cage $\left[\mathrm{C}_{60} @ \mathrm{Pd}_{2} \mathrm{~L}^{1}{ }_{4}\right]^{4+}$ with the $\mathrm{C}_{60}$ guest disordered over two positions, but featuring slightly different Pd-Pd distances (14.66, 14.61, and $14.55 \AA$, respectively) due to a certain degree of backbone flexibility and crystal packing effects (see Figure $4 \mathrm{~b}$ and S108). The average distance from the ligand benzene ring centroids to the center of $\mathrm{C}_{60}$ is $6.72 \AA$ (3.56-3.88 $\AA$ to the six/five membered rings of $\mathrm{C}_{60}$, see Table $S 8)$, verifying that the precisely designed concave inner surface can serve as fullerene receptor through strong $\pi-\pi$ interactions. Similar distances were reported for $\mathrm{C}_{60}$ receptors based on other aromatic systems. ${ }^{17}$ The average distance from pyridine hydrogen $\mathrm{H}_{\mathrm{b}}$ to the $\mathrm{C}_{60}$ centroid is $6.11 \AA$ (2.76-3.29 $\AA$ to the six/five membered rings of $\mathrm{C}_{60}$, see Table S8), further indicating significant contribution from $\mathrm{CH}-\pi$ interactions. Colorless, block-shaped crystals could be grown when tetrahydrofuran (THF) was diffused into the acetonitrile solution of $\left[\mathrm{C}_{60} @ \mathrm{Pd}_{2} \mathrm{~L}_{4}{ }_{4}\right]\left(\mathrm{BF}_{4}\right)_{4}$. X-ray analysis revealed a $\left[\mathrm{Pd}_{2} \mathrm{~L}_{4}{ }_{4}\right]^{4+}$ cage, not containing any fullerenes, but two $\mathrm{BF}_{4}{ }^{-}$ counteranions (Figure $4 \mathrm{a}$ and $\mathrm{S} 107$ ). The $\mathrm{D}_{4 h}$-symmetric cage shows a Pd-Pd distance of $15.94 \AA$. When comparing the geometries of the $\mathrm{BF}_{4}{ }^{-}$-containing cage $\left[\mathrm{Pd}_{2} \mathrm{~L}_{4}{ }_{4}\right]^{4+}$ with the host-guest complex $\left[\mathrm{C}_{60} @ \mathrm{Pd}_{2} \mathbf{L}^{\mathbf{1}}{ }_{4}\right]^{4+}$ it turns out that fullerene binding leads to an averaged $\mathrm{Pd}-\mathrm{Pd}$ distance shortening of 1.3 $\AA$ A. This goes along with a twist of all four ligands in a helical manner around the encapsulated $\mathrm{C}_{60}$. As a result, the dihedral angle between two pyridine arms of the same ligand is $62.3^{\circ}$ (Figure S108), whereas the corresponding dihedral angle in the free cage $\left[\mathrm{Pd}_{2} \mathrm{~L}^{1}{ }^{4+}\right.$ is only $1.0^{\circ}$. Hence, uptake of $\mathrm{C}_{60}$ leads to a conformational change of the cage geometry indicating an induced-fit structural adaptation to perfectly accommodate $\mathrm{C}_{60}$ within the cavity. ${ }^{3 c, 18}$

Self-Assembly of Bowls and Guest Uptake. The initial aim of synthesizing quinoline-modified ligand $\mathbf{L}^{2}$, featuring a larger $\mathrm{N}-\mathrm{N}$ distance than found in $\mathbf{L}^{1}$, was to enlarge the cavity size, thus allowing to accommodate larger guests inside the cage. To our surprise, prolonged heating of a 2:1 mixture of ligand $\mathbf{L}^{2}$ and $\left[\mathrm{Pd}(\mathrm{MeCN})_{4}\right]\left(\mathrm{BF}_{4}\right)_{2}$ in deuterated acetonitrile 
yielded the expected $\left[\mathrm{Pd}_{2} \mathrm{~L}_{4}^{2}\right]^{4+}$ cage only as a minor product, accompanied by a 4 -fold excess of a new species whose peculiar ${ }^{1} \mathrm{H}$ NMR signal pattern as well as unambiguous mass spectral features allowed us to assign it to bowl-shaped compound $\left[\mathrm{Pd}_{2} \mathbf{L}_{3}{ }_{3}(\mathrm{MeCN})_{2}\right]^{4+}$, explainable as a $\left[\mathrm{Pd}_{2} \mathbf{L}_{4}^{2}\right]$ cage lacking the fourth ligand (Figure S19 and S22). Previous work on Pd-mediated assembly with banana-shaped bis-monodentate pyridyl ligands never reported such bowl species (however, few reports exist for sterically more demanding ligand systems). ${ }^{19}$ Closer inspection of the steric situation around the metal coordination sites suggested that the quinolines' hydrogen atoms $\left(\mathrm{H}_{\mathrm{c}}\right)$ adjacent to the coordinating nitrogen atoms seem to cause significant steric crowding. This hypothesis was indeed supported by the observation that reacting ligand $\mathrm{L}^{2}$ with $\left[\mathrm{Pd}(\mathrm{MeCN})_{4}\right]\left(\mathrm{BF}_{4}\right)_{2}$ in a $3: 2$ ratio at room temperature yielded $\left[\mathrm{Pd}_{2} \mathrm{~L}_{3}{ }_{3}(\mathrm{MeCN})_{2}\right]^{4+}$ as a single product after 2 days. Further proof for the suggested bowl geometry came from characteristic cross peaks in the sample's ${ }^{1} \mathrm{H}-{ }^{1} \mathrm{H}$ NOESY NMR spectrum (Figure S15), the quinoline moieties' ${ }^{1} \mathrm{H}$ signal splitting into two sets with 2:1 integral ratio and the observation of prominent peaks in the ESI mass spectrum consistent with the formula $\left[\mathrm{Pd}_{2} \mathrm{~L}_{3}{ }_{3}(\mathrm{MeCN})_{2}\right]^{4+}$, alongside further adducts with various anions $\left[\mathrm{Pd}_{2} \mathrm{~L}_{3}{ }_{3}(\mathrm{MeCN})\right.$ $+\mathrm{X}]^{3+}\left(\mathrm{X}=\mathrm{F}^{-}, \mathrm{Cl}^{-}, \mathrm{BF}_{4}^{-}\right)$. Surprisingly, slow vapor diffusion of isopropyl ether into a $\mathrm{MeCN}$ solution of bowl $\left[\mathrm{Pd}_{2} \mathrm{~L}_{3}^{2}(\mathrm{MeCN})_{2}\right]^{4+}$ produced single crystals for which a synchrotron-based diffraction experiment revealed the structure of cage $\left[\mathrm{Pd}_{2} \mathrm{~L}_{4}^{2}\right]^{4+}$ (Figure $4 \mathrm{~d}$ ), indicating the fine energetic balance between these two species.

Owing to the bowl's open geometry, we found $\left[\mathrm{Pd}_{2} \mathrm{~L}_{3}^{2}(\mathrm{MeCN})_{2}\right]^{4+}$ to be able to bind both $\mathrm{C}_{60}$ to give $\left[\mathrm{C}_{60} @ \mathrm{Pd}_{2} \mathrm{~L}_{3}{ }_{3}(\mathrm{MeCN})_{2}\right]^{4+}$ and $\mathrm{C}_{70}$ to yield $\left[\mathrm{C}_{70} @\right.$ $\left.\mathrm{Pd}_{2} \mathbf{L}_{3}^{2}(\mathrm{MeCN})_{2}\right]^{4+}$ in a quantitative manner, both accompanied by characteristic color changes. In a competitive binding experiment, exposing bowl $\left[\mathrm{Pd}_{2} \mathrm{~L}_{3}^{2}(\mathrm{MeCN})_{2}\right]^{4+}$ to an equimolar mixture of powdered $\mathrm{C}_{60} / \mathrm{C}_{70}$ ( 5 equiv $/ 5$ equiv), preferred binding of $\mathrm{C}_{70}$ was observed (ratio of $\left[\mathrm{C}_{70} @\right.$ $\left.\mathrm{Pd}_{2} \mathrm{~L}_{3}{ }_{3}(\mathrm{MeCN})_{2}\right]^{4+}$ to $\left[\mathrm{C}_{60} @ \mathrm{Pd}_{2} \mathrm{~L}^{2}{ }_{3}(\mathrm{MeCN})_{2}\right]^{4+} \approx 4: 1$; Figure S78). The UV-vis spectrum of $\left[\mathrm{C}_{60} @\right.$ $\left.\mathrm{Pd}_{2} \mathbf{L}_{3}{ }_{3}(\mathrm{MeCN})_{2}\right]^{4+}$ in acetonitrile showed a shoulder ranging from 330 to $420 \mathrm{~nm}$ compared to empty bowl $\left[\mathrm{Pd}_{2} \mathrm{~L}_{3}^{2}(\mathrm{MeCN})_{2}\right]^{4+}$, whereas $\left[\mathrm{C}_{70} @ \mathrm{Pd}_{2} \mathrm{~L}_{3}^{2}(\mathrm{MeCN})_{2}\right]^{4+}$ displayed enhanced absorption in the longer wavelength region with one band around $\lambda_{\max }=383$ and a broad band around 473 $\mathrm{nm}$ (Figure S105). Interestingly, the herein observed spectral features of fullerenes bound to a rather electron-deficient host differ significantly from Yosizawa's recent report on binding the same fullerenes to electron-rich anthracene-based hosts in the same solvent. ${ }^{5 b}$ In the ${ }^{1} \mathrm{H}$ NMR spectra of the host-guest complexes, protons $\mathrm{H}_{\mathrm{b}}, \mathrm{H}_{\mathrm{b}^{\prime}}, \mathrm{H}_{\mathcal{c}}$ and $\mathrm{H}_{\mathrm{c}^{\prime}}$, located inward from the coordination sites, show distinct shifts upon binding of the fullerenes within the bowl (Figure 2b). ESI mass spectrometry unambiguously supported the formation of the 1:1 host-guest complexes, while partial substitution of the acetonitrile ligands by trace amounts of anions was observed (Figure 2c). Consequently, we titrated 2 equiv of a solution of tetrabutylammonium chloride into a solution of bowl $\left[\mathrm{Pd}_{2} \mathrm{~L}_{3}^{2}(\mathrm{MeCN})_{2}\right]^{4+}$, which afforded a quantitative conversion into compound $\left[\mathrm{Pd}_{2} \mathrm{~L}_{3}{ }_{3} \mathrm{Cl}_{2}\right]^{2+}$. Likewise, the fullerene carrying complexes could be converted into chloride-coordinated species, thus giving rise to very clean NMR and mass spectral results (Figure S42 and S45). We evaluated the thermal stability of the different bowl species in solution and found that a)

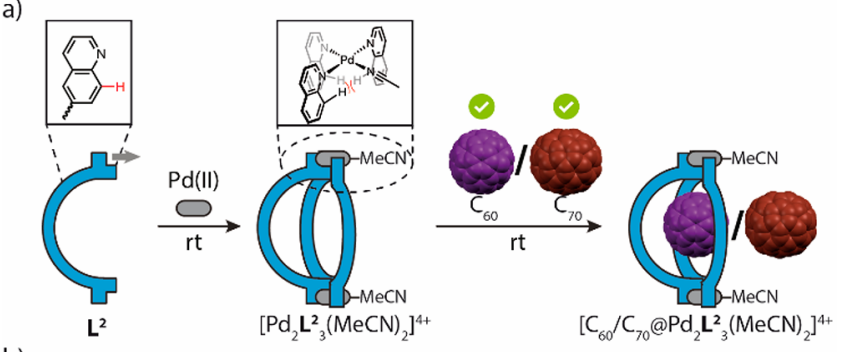

b)

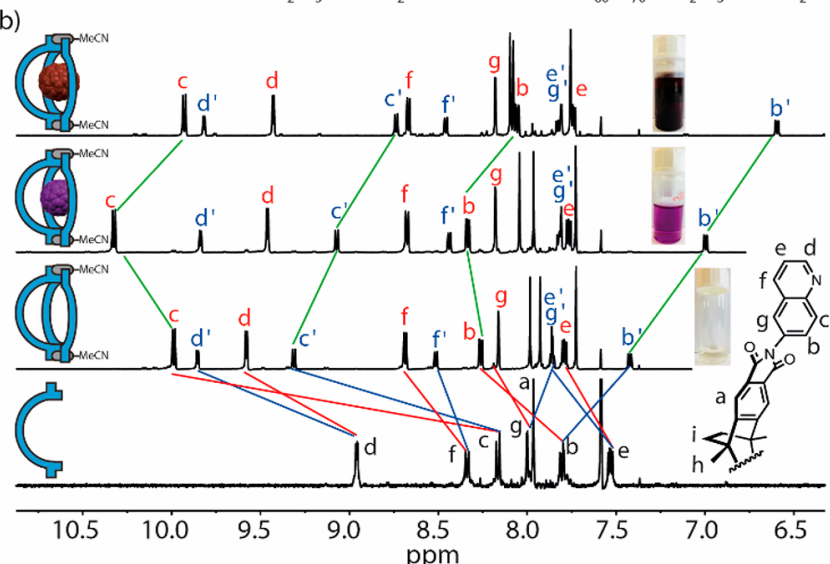

c)

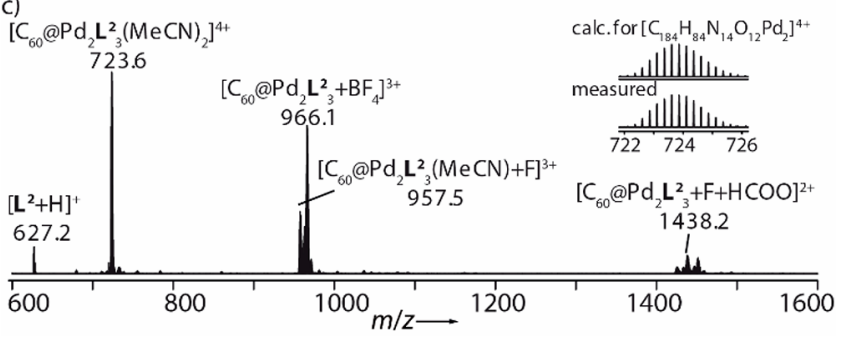

Figure 2. Self-assembly and characterization of bowl compounds. (a) $\mathbf{L}^{2}$, comprising sterically demanding quinoline donors, reacts with $\mathrm{Pd}^{\mathrm{II}}$ to the bowl-shaped host, which binds both $\mathrm{C}_{60}$ and $\mathrm{C}_{70}$. (b) ${ }^{1} \mathrm{H}$ NMR spectra of ligand $\mathrm{L}^{2}\left(600 \mathrm{MHz}, 298 \mathrm{~K}, \mathrm{CD}_{3} \mathrm{CN}\right)$, bowl $\left[\mathrm{Pd}_{2} \mathrm{~L}_{3}{ }_{3}(\mathrm{MeCN})_{2}\right]^{4+},\left[\mathrm{C}_{60} @ \mathrm{Pd}_{2} \mathrm{~L}_{3}{ }_{3}(\mathrm{MeCN})_{2}\right]^{4+},\left[\mathrm{C}_{70} @\right.$ $\left.\mathrm{Pd}_{2} \mathrm{~L}_{3}^{2}(\mathrm{MeCN})_{2}\right]^{4+}$ (all $0.64 \mathrm{mM}, 298 \mathrm{~K}, \mathrm{CD}_{3} \mathrm{CN}$ ) and photos of solutions. Red and blue marked proton signals are assigned to edge and central ligands, respectively. (c) High resolution ESI mass spectrum of $\left[\mathrm{C}_{60} @ \mathrm{Pd}_{2} \mathrm{~L}_{3}{ }_{3}(\mathrm{MeCN})_{2}\right]^{4+}$, prepared in pure $\mathrm{CH}_{3} \mathrm{CN}$.

$\left[\mathrm{Pd}_{2} \mathrm{~L}_{3}{ }_{3}(\mathrm{MeCN})_{2}\right]^{4+}$ and $\left[\mathrm{C}_{70} @ \mathrm{Pd}_{2} \mathrm{~L}_{3}{ }_{3}(\mathrm{MeCN})_{2}\right]^{4+}$ partly converted into $\left[\mathrm{Pd}_{2} \mathrm{~L}_{4}^{2}\right]^{4+}$ and $\left[\mathrm{C}_{70} @ \mathrm{Pd}_{2} \mathbf{L}_{4}^{2}\right]^{4+}$, respectively, upon prolonged heating at $70{ }^{\circ} \mathrm{C}$, whereas $\left[\mathrm{C}_{60} @\right.$ $\left.\mathrm{Pd}_{2} \mathrm{~L}_{3}^{2}(\mathrm{MeCN})_{2}\right]^{4+}$ remained unchanged under these conditions (Figure S18, S29 and S36).

We were able to obtain the single crystal X-ray structures of ligand $\mathbf{L}^{2}$, cage $\left[\mathrm{Pd}_{2} \mathbf{L}_{4}^{2}\right]^{4+}$, and host-guest complex $\left[\mathrm{C}_{60} @\right.$ $\left.\mathrm{Pd}_{2} \mathrm{~L}_{3}{ }_{3}(\mathrm{MeCN})_{2}\right]^{4+}$ (Figure $4 \mathrm{c}-\mathrm{e}$ ), thus allowing us to compare structural features between $\mathbf{L}^{2}$ in its free form, as part of the cage as well as the bowl geometry. In case of the free ligand and cage $\left[\mathrm{Pd}_{2} \mathrm{~L}^{2}{ }^{4+}\right.$, angles between the backbone's benzene planes are $119.8^{\circ}$ and $120.2^{\circ}$, respectively, while slight widening $\left(123.9^{\circ}\right)$ was observed in case of the bowl. Likewise, the ligands' $\mathrm{N}-\mathrm{N}$ distance of $19.11 \AA$ for free $\mathrm{L}^{2}$ and $\mathrm{Pd}-\mathrm{Pd}$ distance of $18.80 \AA$ for cage $\left[\mathrm{Pd}_{2} \mathrm{~L}_{4}^{2}\right]^{4+}$ compared to $20.22 \AA$ for bowl $\left[\mathrm{C}_{60} @ \mathrm{Pd}_{2} \mathrm{~L}_{3}^{2}(\mathrm{MeCN})_{2}\right]^{4+}$ indicate a slight opening of the cavity when the fourth ligand is missing. Of particular interest is comparing the immediate ligand environment around the $\mathrm{Pd}^{\mathrm{II}}$ cations in the cage and bowl structures: as expected, the quinoline $\mathrm{H}_{\mathrm{c}}$ hydrogen substituents lead to 
significant steric crowding in case of cage $\left[\mathrm{Pd}_{2} \mathrm{~L}_{4}^{2}\right]^{4+}$, where four protons have to squeeze in the small space under the coordinated metal cation, leading to an average $\mathrm{H}-\mathrm{H}$ distances of $2.31 \AA$ (less than double the van-der-Waals radius of hydrogen, $1.2 \AA$ ) and a small deviation of the $\mathrm{Pd}^{\mathrm{II}}$-coordination geometry from planarity with $\mathrm{N}-\mathrm{Pd}-\mathrm{N}$ angles of $176^{\circ} .{ }^{19}$ Even more compelling is the situation in the quinoline-based bowl $\left[\mathrm{C}_{60} @ \mathrm{Pd}_{2} \mathrm{~L}_{3}^{2}(\mathrm{MeCN})_{2}\right]^{4+}$ : here, the $\mathrm{H}_{\mathrm{c}^{\prime}}$ hydrogen substituent belonging to the central ligand pushes both $\mathrm{H}_{\mathrm{c}}$ hydrogens of adjacent quinolines aside in direction of the lean acetonitrile ligand, giving rise to $\mathrm{H}-\mathrm{H}$ distances of $2.56,2.50$, and $2.47 \AA$. In this bowl structure, the average distance from the ligand benzene ring centroids to the center of $\mathrm{C}_{60}$ is $6.79 \AA$ (3.67$3.93 \AA$ to the six/five membered rings of $\mathrm{C}_{60}$, see Table S14), and the average distance from quinoline $\mathrm{H}_{\mathrm{b}}$ hydrogens to the $\mathrm{C}_{60}$ centroid is $6.39 \AA$ (2.92-3.53 $\AA$ to the six/five membered rings of $\mathrm{C}_{60}$, Table $\left.\mathrm{S} 14\right)$, which are all slightly longer than the corresponding distances in $\left[\mathrm{C}_{60} @ \mathrm{Pd}_{2} \mathrm{~L}_{4}^{1}\right]^{4+}$, still indicating both $\pi-\pi$ and $\mathrm{CH}-\pi$ interactions between $\mathrm{C}_{60}$ and the bowl.

Bowl-Protected Diels-Alder Reaction of $\mathrm{C}_{60}$ with Anthracene $(\mathrm{Ac})$. As observed in the crystal structure of $\left[\mathrm{C}_{60} @ \mathrm{Pd}_{2} \mathrm{~L}_{3}^{2}(\mathrm{MeCN})_{2}\right]\left(\mathrm{BF}_{4}\right)_{4}$ (Figure 4e), most of the $\mathrm{C}_{60}$ surface is covered by the bowl geometry, while exposing only a patch measuring about $25 \%$ of the total surface area to the acetonitrile solution environment. In order to elucidate whether the bowl-shaped host can modulate the fullerene's chemical reactivity, we subjected complex $\left[\mathrm{C}_{60} @ \mathrm{Pd}_{2} \mathrm{~L}_{3}^{2} \mathrm{Cl}_{2}\right]^{2+}$ (featuring chloride instead of acetonitrile ligands) to a DielsAlder reaction with anthracene. The same reaction had been studied before within a cubic coordination cage and a metalorganic-framework, both leading to formation of the bisadduct. $^{3 a, 20}$ With pure $\mathrm{C}_{60}$, this reaction requires the use of problematic solvents such as benzene, chlorinated aromatics or $\mathrm{CS}_{2}$ and is known to deliver mixtures of mono-, di-, or even triadducts. $^{21}$ Our system, on the other hand, allows the smooth conversion into the anthracene monoadduct (90\% yield) when a MeCN solution of $\left[\mathrm{C}_{60} @ \mathrm{Pd}_{2} \mathrm{~L}_{3}^{2} \mathrm{Cl}_{2}\right]^{2+}(0.56 \mathrm{mM}, 1$ equiv $)$ is treated with up to 10 equiv of anthracene at $50{ }^{\circ} \mathrm{C}$ in the dark under a nitrogen atmosphere for about $12 \mathrm{~h}$ (equilibrium constant $K_{323}=2210 \mathrm{~L} \mathrm{~mol}^{-1}$ ) (Figure S99 and Table S1).

The ${ }^{1} \mathrm{H}$ NMR spectrum of the reaction product shows upfield shifts of bowl protons $\mathrm{H}_{\mathrm{b}}, \mathrm{H}_{\mathrm{b}^{\prime}}, \mathrm{H}_{\mathrm{c}}, \mathrm{H}_{\mathrm{c}^{\prime}}$. DOSY NMR analysis reveals that both the guest's and host's ${ }^{1} \mathrm{H}$ NMR signals belong to a single species with a hydrodynamic radius of about 10.0 $\AA$. The ESI mass spectrum shows a single peak for the expected $\left[\mathrm{C}_{60} \mathrm{Ac} @ \mathrm{Pd}_{2} \mathrm{~L}_{3}^{2} \mathrm{Cl}_{2}\right]^{2+}$ ion (Figure $3 \mathrm{~b}$ and $3 \mathrm{c}$ ). We were further able to obtain single crystals of $\left[\mathrm{C}_{60} \mathrm{Ac} @\right.$ $\left.\mathrm{Pd}_{2} \mathbf{L}_{3}{ }_{3} \mathrm{Cl}_{2}\right]\left(\mathrm{BF}_{4}\right)_{2}$ (Figure $4 \mathrm{f}$ ), thereby delivering the first X-ray crystallographic report of the $\mathrm{C}_{60}$-anthracene monoadduct structure, which is a light- and oxygen-sensitive compound in solution. The structure reveals that no second anthracene molecule would be able to add to the encapsulated guest for steric reasons. Interestingly, unlike the disordered $\mathrm{C}_{60}$ guests in the other structures, substituted fullerene $\mathrm{C}_{60} \mathrm{Ac}$ could be refined without geometrical restraints and did not require modeling of a second conformer. The fused substituent is not positioned in the middle of the window of the bowl structure, but rather tilted to one side (presumably for maximizing a stabilizing $\mathrm{CH}-\mathrm{O}$ contact measuring $2.2 \AA$ between one of the guest's bridgehead protons and a ligand oxygen). Since no signal splitting is observed in the ${ }^{1} \mathrm{H}$ NMR spectrum of the host-guest complex that would point to such a fixed, unsymmetrical conformation existing in solution, we expect

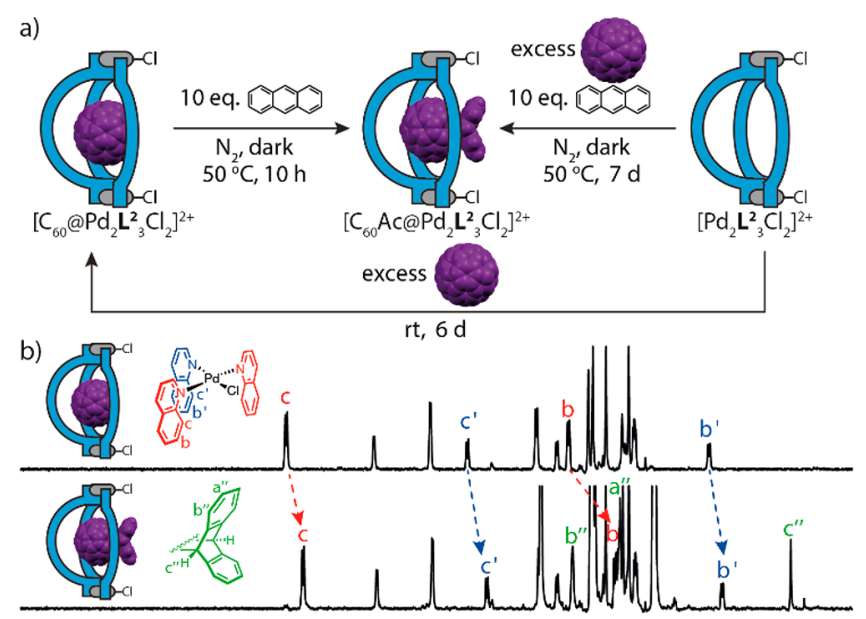

$\log D=-9.23, r=10.0 \AA-1 \ldots+\cdots+\cdots$

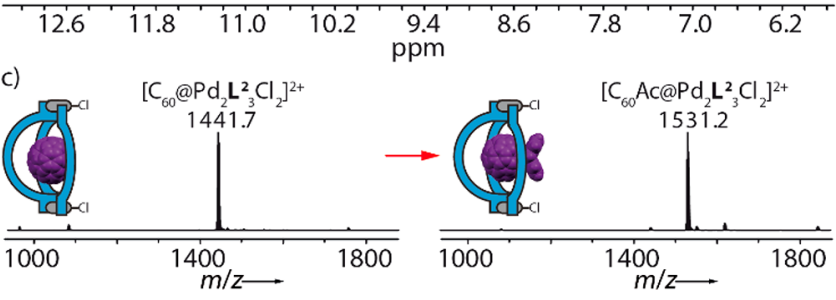

Figure 3. Diels-Alder reaction between $\mathrm{C}_{60}$ and anthracene within the host-guest complex $\left[\mathrm{C}_{60} @ \mathrm{Pd}_{2} \mathrm{~L}_{3}^{2} \mathrm{Cl}_{2}\right]^{2+}$. (a) Stepwise or one-pot access to the encapsulated monoadduct. (b) Comparison of ${ }^{1} \mathrm{H}$ NMR spectra $\left(500 \mathrm{MHz}, 298 \mathrm{~K}, \mathrm{CD}_{3} \mathrm{CN}\right)$ of $\left[\mathrm{C}_{60} @ \mathrm{Pd}_{2} \mathrm{~L}_{3}{ }_{3} \mathrm{Cl}_{2}\right]^{2+}(0.56$ $\mathrm{mM})$ and $\left[\mathrm{C}_{60} \mathrm{Ac} @ \mathrm{Pd}_{2} \mathrm{~L}_{3}{ }_{3} \mathrm{Cl}_{2}\right]^{2+}(0.36 \mathrm{mM})$, DOSY trace showing all aromatic signals of $\left[\mathrm{C}_{60} \mathrm{Ac} @ \mathrm{Pd}_{2} \mathrm{~L}_{3}{ }_{3} \mathrm{Cl}_{2}\right]^{2+}$ having the same diffusion coefficient. (c) ESI high resolution mass spectra of $\left[\mathrm{C}_{60} @\right.$ $\left.\mathrm{Pd}_{2} \mathrm{~L}_{3} \mathrm{Cl}_{2}\right]^{2+}$ and $\left[\mathrm{C}_{60} \mathrm{Ac} @ \mathrm{Pd}_{2} \mathrm{~L}_{3} \mathrm{Cl}_{2}\right]^{2+}$.

the system to show a dynamic behavior comparable to a balland-socket joint.

Dimerization of Bowls to Give Difullerene Complexes. With the X-ray structures of bowls $\left[\mathrm{C}_{60} @\right.$ $\left.\mathrm{Pd}_{2} \mathbf{L}_{3}{ }_{3}(\mathrm{MeCN})_{2}\right]^{4+}$ and $\left[\mathrm{C}_{60} \mathrm{Ac} @ \mathrm{Pd}_{2} \mathbf{L}_{3}^{2} \mathrm{Cl}_{2}\right]^{2+}$ in hand, carrying acetonitrile and chloride ligands, respectively, to complement the $\mathrm{Pd}(\mathrm{II})$ square-planar coordination environments, the question arose whether other, sterically lowdemanding donors could be installed in this position as well. Comparable to Stang's methodology of mixing $\mathrm{N}$-donor with carboxylate ligands, ${ }^{12}$ we succeeded in substituting both of the bowl's acetonitriles with carboxylate anions. Most interestingly, this allowed us to cleanly dimerize two bowls into pill-shaped assemblies using two terephthalate bridges (BDC, Figure 5). Dimerization could be shown for the empty bowl and its $\mathrm{C}_{60}$ as well as $\mathrm{C}_{70}$ complexes, as unambiguously demonstrated by NMR, UV-vis spectra, and ESI MS results.

The ${ }^{1} \mathrm{H}$ NMR spectrum of the guest-free dimer shows the 2:1 signal splitting for the quinoline moieties retained and a single signal for the four protons of the phenylene bridge, indicating the formation of a single product containing the terephthalates symmetrically joining two identical halves. The dimer binds two fullerenes $\left(\mathrm{C}_{60}\right.$ or $\left.\mathrm{C}_{70}\right)$ without experiencing any further symmetry-related signal splitting effects. Encapsulation-induced chemical shift changes are analogous to what was observed for the monomeric bowls (compare Figures $2 \mathrm{~b}$ and $5 \mathrm{~b})$. Further, taking $\mathrm{C}_{60}$-occupied dimer [2 $\mathrm{C}_{60} @$ $\left.\mathrm{Pd}_{4} \mathrm{~L}_{6}{ }_{6}(\mathrm{BDC})_{2}\right]^{4+}$ as an example, the NOE NMR spectrum 


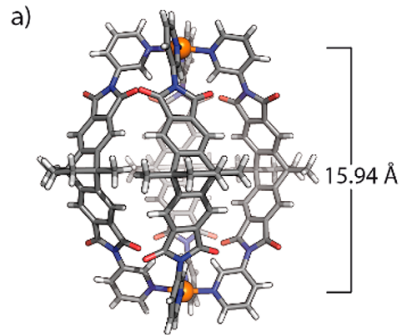

c)

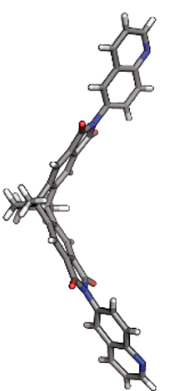

e)
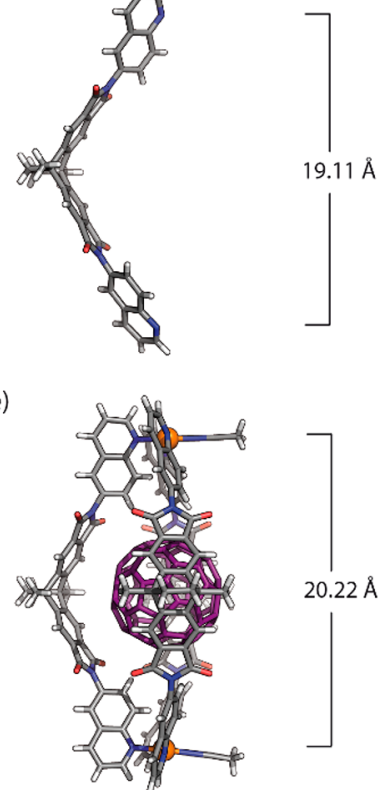

b)

d)

f)

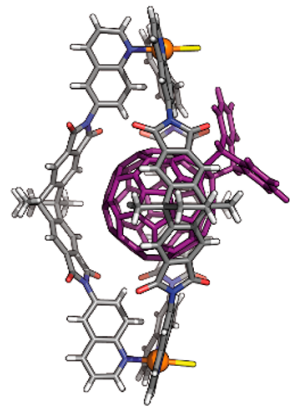

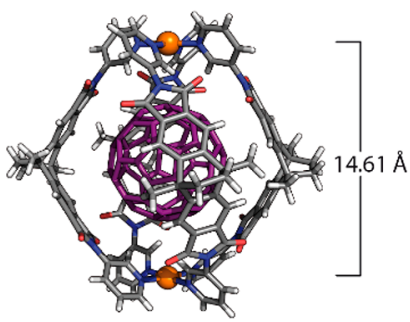

a)
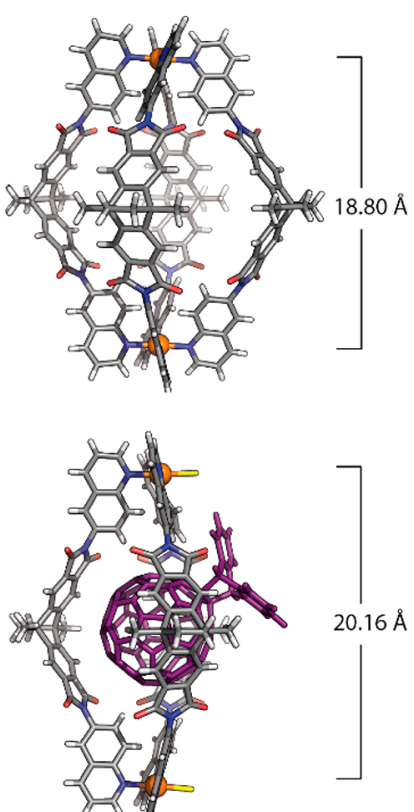

Figure 4. X-ray crystal structures. (a) $\left[\mathrm{Pd}_{2} \mathbf{L}_{4}^{1}\right]^{4+}$, (b) $\left[\mathrm{C}_{60} @\right.$ $\left.\mathrm{Pd}_{2} \mathbf{L}_{4}{ }^{4}\right]^{4+}$, (c) $\mathbf{L}^{2}$, (d) $\left[\mathrm{Pd}_{2} \mathbf{L}^{2}{ }_{4}\right]^{4+}$, (e) $\left[\mathrm{C}_{60} @ \mathrm{Pd}_{2} \mathbf{L}^{2}{ }_{3}(\mathrm{MeCN})_{2}\right]^{4+}$, and (f) $\left[\mathrm{C}_{60} \mathrm{Ac} @ \mathrm{Pd}_{2} \mathrm{~L}_{3}{ }_{3} \mathrm{Cl}_{2}\right]^{2+}$. Solvent molecules, anions, guest disorder and outside of cage and bowl structures are omitted for clarity ( $\mathrm{Pd}^{\mathrm{II}}$, orange; $\mathrm{C}$, gray; $\mathrm{N}$, blue; $\mathrm{O}$, red; $\mathrm{Cl}$, yellow; $\mathrm{H}$, white; $\mathrm{C}_{60}$ and $\mathrm{C}_{60} \mathrm{Ac}$, purple).

reveals a contact between signals $\mathrm{H}_{\mathrm{c}}$ of the flanking quinolines (but not $\mathrm{H}_{\mathrm{c}^{\prime}}$ of the central one) and the terephthalate proton $\mathrm{H}_{\mathrm{A}}$, in accordance with the relatively short distance between these atoms observed in the PM6-optimized structure (Figure $5 \mathrm{~d}$ and Figure S60). Furthermore, the increase in size from monomeric bowl to the pill-shaped dimer was confirmed by DOSY experiments, giving diffusion coefficients of $5.20 \times$ $10^{-10} \mathrm{~m}^{2} \mathrm{~s}^{-1}$ for the monomer (Figure S27) and $4.08 \times 10^{-10}$ $\mathrm{m}^{2} \mathrm{~s}^{-1}$ for the dimer (Figure S62). Comparison of UV-vis spectra of empty and fullerene-filled dimers shows very similar absorption bands compared to the monomeric bowl system, further confirming the binding of fullerenes within the inner cavities (Figure S106). The high-resolution ESI mass spectrum of the dimer revealed prominent signals at $\mathrm{m} / z 1488.7$ and 2014.0, consistent with the simulated isotopic pattern of formulas $\left[2 \mathrm{C}_{60} @ \mathrm{Pd}_{4} \mathrm{~L}_{6}{ }_{6}(\mathrm{BDC})_{2}+n \mathrm{BF}_{4}\right]^{(4-n)+}(n=0,1)$ (Figure 5c). Analogous NMR and MS results were also obtained for the guest-free (Figure S53-57) and $\left(\mathrm{C}_{70}\right)_{2}$ containing (Figure S64-69) dimers, showing that guest encapsulation is orthogonal to the dimerization process.

\section{CONCLUSIONS}

On the basis of a rational design approach, we synthesized new self-assembled, low-weight fullerene receptors that allow the solution handling and facile crystallization of fullerenes as well
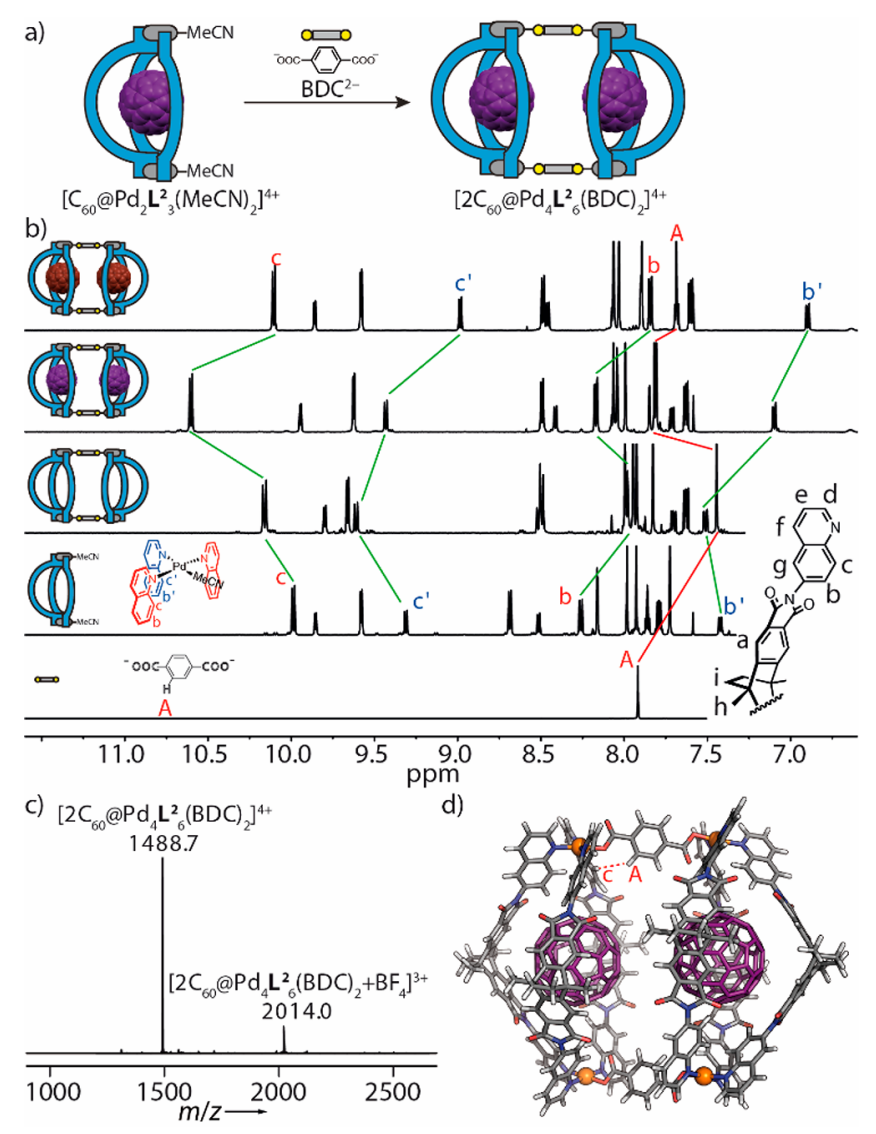

Figure 5. Hierarchical assembly and characterization of pill-shaped dimers. (a) Bowl $\left[\mathrm{C}_{60} @ \mathrm{Pd}_{2} \mathrm{~L}_{3}^{2}(\mathrm{MeCN})_{2}\right]^{4+}$ reacts with terephthalate $\left(\mathrm{BDC}^{2-}\right)$ to form dimer $\left[2 \mathrm{C}_{60} @ \mathrm{Pd}_{4} \mathrm{~L}_{6}^{2}(\mathrm{BDC})_{2}\right]^{4+}$. (b) ${ }^{1} \mathrm{H} \mathrm{NMR}$ spectra $\left(600 \mathrm{MHz}, 298 \mathrm{~K}, \mathrm{CD}_{3} \mathrm{CN}\right)$ of $\mathrm{BDC}^{2-}(15 \mathrm{mM})$, $\left[\mathrm{Pd}_{2} \mathrm{~L}_{3}^{2}(\mathrm{MeCN})_{2}\right]^{4+}(0.64 \mathrm{mM}),\left[\mathrm{Pd}_{4} \mathrm{~L}_{6}^{2}(\mathrm{BDC})_{2}\right]^{4+}(0.31 \mathrm{mM})$, $\left[2 \mathrm{C}_{60} @ \mathrm{Pd}_{4} \mathrm{~L}_{6}^{2}(\mathrm{BDC})_{2}\right]^{4+}(0.31 \mathrm{mM})$, and $\left[2 \mathrm{C}_{70} @ \mathrm{Pd}_{4} \mathrm{~L}^{2}{ }_{6}(\mathrm{BDC})_{2}\right]^{4+}$ $(0.31 \mathrm{mM})$ (from bottom to top). Red and blue marked proton signals are assigned to edge and central ligands in the bowl geometries, respectively. (c) High-resolution ESI mass spectrum of $\left[2 \mathrm{C}_{60} @ \mathrm{Pd}_{4} \mathrm{~L}_{6}^{2}(\mathrm{BDC})_{2}\right]^{4+}$. (d) PM6-optimized structure of $\left[2 \mathrm{C}_{60} @\right.$ $\left.\mathrm{Pd}_{4} \mathrm{~L}_{6}^{2}(\mathrm{BDC})_{2}\right]^{4+}$.

as their adducts. The first receptor, consisting of pyridylterminated, bent ligands assembling with $\mathrm{Pd}^{\mathrm{II}}$ cations to a $\left[\mathrm{Pd}_{2} \mathrm{~L}_{4}{ }_{4}\right]^{4+}$ cage, is highly selective for $\mathrm{C}_{60}$. The second receptor was assembled using quinoline donors, which-owing to their steric demand-led to an unprecedented $\left[\mathrm{Pd}_{2} \mathrm{~L}_{3}^{2}(\mathrm{MeCN})_{2}\right]^{4+}$ bowl geometry. This bowl not only was found to display a wider guest encapsulation scope (including $\mathrm{C}_{70}$ ), but also is capable of serving as a supramolecular protecting group, allowing selective monofunctionalization of its fullerene guest. We further show that these bowls, both with and without bound fullerenes, can be cleanly dimerized by exchanging the acetonitrile ligands for terephthalate bridges, giving large, pill-shaped architectures of heteroleptic nature. The herein introduced receptors have the potential to serve as new tools for handling fullerenes and their derivatives in a wider range of organic solvents, and further allow their selective uptake and regioselective modification. Applications related to advanced fullerene derivatization, purification, structure elucidation, and device fabrication are sought to benefit from our findings. 


\section{ASSOCIATED CONTENT}

\section{S Supporting Information}

The Supporting Information is available free of charge on the ACS Publications website at DOI: 10.1021/jacs.9b02207.

Experimental details and further NMR, MS, UV-vis and crystal data (PDF)

Crystal data for $\left[\mathrm{C}_{60} \mathrm{Ac} @ \mathrm{Pd}_{2} \mathrm{~L}_{3}^{2} \mathrm{Cl}_{2}\right]$, CCDC 1858158 (CIF)

Crystal data for $\left[\mathrm{C}_{60} @ \mathrm{Pd}_{2} \mathrm{~L}_{3}^{2}(\mathrm{MeCN})_{2}\right], \quad \mathrm{CCDC}$ 1850362 (CIF)

Crystal data for $\left[\mathrm{Pd}_{2} \mathrm{~L}_{4}^{2}\right], \mathrm{CCDC} 1850361$ (CIF)

Crystal data for $\mathrm{L}^{2}$, CCDC 1850360 (CIF)

Crystal data for $\left[\mathrm{C}_{60} @ \mathrm{Pd}_{2} \mathrm{~L}_{4}{ }_{4}\right], \mathrm{CCDC} 1850359$ (CIF)

Crystal data for $\left[\mathrm{Pd}_{2} \mathrm{~L}_{4}{ }_{4}\right]$, CCDC 1850358 (CIF)

\section{AUTHOR INFORMATION}

Corresponding Author

*guido.clever@tu-dortmund.de

\section{ORCID $\odot$}

Julian J. Holstein: 0000-0002-8385-7805

Shinnosuke Horiuchi: 0000-0002-5692-6377

Guido H. Clever: 0000-0001-8458-3060

Notes

The authors declare no competing financial interest.

\section{ACKNOWLEDGMENTS}

B.C. thanks the China Scholarship Council for a $\mathrm{PhD}$ fellowship. S.H. thanks the JSPS program for Advancing Strategic International Networks to Accelerate the Circulation of Talented Researchers. We thank the European Research Council (ERC Consolidator grant 683083, RAMSES) and the DFG (RESOLV Cluster of Excellence EXC 2033, project number 390677874, and GRK2376 "Confinement-controlled Chemistry”, project number 331085229) for support. We thank Christiane Heitbrink and Laura Schneider for measuring ESI mass spectra and André Platzek for measuring DOSY spectra. Diffraction data of $\left[\mathrm{Pd}_{2} \mathbf{L}_{4}{ }_{4}\right]\left(\mathrm{BF}_{4}\right)_{4}, \quad\left[\mathrm{C}_{60} @ \mathrm{Pd}_{2} \mathbf{L}_{4}{ }_{4}\right]$ $\left(\mathrm{BF}_{4}\right)_{4},\left[\mathrm{Pd}_{2} \mathrm{~L}_{4}{ }_{4}\right]\left(\mathrm{BF}_{4}\right)_{4}$, and $\left[\mathrm{C}_{60} \mathrm{Ac} @ \mathrm{Pd}_{2} \mathrm{~L}_{3}^{2} \mathrm{Cl}_{2}\right]\left(\mathrm{BF}_{4}\right)_{2}$ was collected at PETRA III, DESY, a member of the Helmholtz Association (HGF). We thank Saravanan Panneerselvam, Sebastian Guenther, and Eva Crosas for assistance in using synchrotron beamline P11 (I-20170404 and I-20170714).

\section{REFERENCES}

(1) Langa, F.; Nierengarten, J.-F. Fullerenes: Principles and Applications, 2nd ed.; RSC: Cambridge, 2011; pp 191-328.

(2) Hirsch, A.; Brettreich, M. Fullerenes: Chemistry and Reactions; VCH: Weinheim, 2005; pp 24-29.

(3) (a) Brenner, W.; Ronson, T. K.; Nitschke, J. R. Separation and selective formation of fullerene adducts within an $\mathrm{M}^{\mathrm{II}}{ }_{8} \mathrm{~L}_{6}$ cage. J. Am. Chem. Soc. 2017, 139, 75-78. (b) García-Simón, C.; Costas, M.; Ribas, X. Metallosupramolecular receptors for fullerene binding and release. Chem. Soc. Rev. 2016, 45, 40-62. (c) García-Simón, C.; Monferrer, A.; Garcia-Borràs, M.; Imaz, I.; Maspoch, D.; Costas, M.; Ribas, X. Size-selective encapsulation of $\mathrm{C}_{60}$ and $\mathrm{C}_{60}$-derivatives within an adaptable naphthalene-based tetragonal prismatic supramolecular nanocapsule. Chem. Commun. 2019, 55, 798-801. (d) Han, W. K.; Zhang, H. X.; Wang, Y.; Liu, W.; Yan, X.; Li, T.; Gu, Z. G. Tetrahedral metal-organic cages with cube-like cavities for selective encapsulation of fullerene guests and their spin-crossover properties. Chem. Commun. 2018, 54, 12646-12649. (e) Martínez-Agramunt, V.; Eder, T.; Darmandeh, H.; Guisado-Barrios, G.; Peris, E. A SizeFlexible Organometallic Box for the Encapsulation of Fullerenes.
Angew. Chem., Int. Ed. 2019, 2019 (58), 5682-5686. (f) Suzuki, K.; Takao, K.; Sato, S.; Fujita, M. Coronene nanophase within coordination spheres: increased solubility of $\mathrm{C}_{60}$. J. Am. Chem. Soc. 2010, 132, 2544-2545. (g) Mahata, K.; Frischmann, P. D.; Würthner, F. Giant electroactive $\mathrm{M}_{4} \mathrm{~L}_{6}$ tetrahedral host self-assembled with $\mathrm{Fe}(\mathrm{II})$ vertices and perylenebisimide dye edges. J. Am. Chem. Soc. 2013, 135, 15656-15661. (h) Rizzuto, F. J.; Nitschke, J. R. Stereochemical plasticity modulates cooperative binding in a $\mathrm{Co}^{\mathrm{II}}{ }_{12} \mathrm{~L}_{6}$ cuboctahedron. Nat. Chem. 2017, 9, 903-908. (i) Kawano, S. I.; Fukushima, T.; Tanaka, K. Specific and oriented encapsulation of fullerene $\mathrm{C}_{70}$ into a supramolecular double-decker cage composed of shape-persistent macrocycles. Angew. Chem., Int. Ed. 2018, 57, 14827-14831. (j) Fuertes-Espinosa, C.; Gómez-Torres, A.; MoralesMartínez, R.; Rodríguez-Fortea, A.; García-Simón, C.; Gandara, F.; Imaz, I.; Juanhuix, J.; Maspoch, D.; Poblet, J. M.; Echegoyen, L.; Ribas, X. Purification of uranium-based endohedral metallofullerenes (EMFs) by selective supramolecular encapsulation and release. Angew. Chem., Int. Ed. 2018, 57, 11294-11299. (k) Ikeda, A.; Yoshimura, M.; Udzu, H.; Fukuhara, C.; Shinkai, S. Inclusion of [60]fullerene in a homooxacalix[3] arene-based dimeric capsule cross-linked by a $\mathrm{Pd}^{\mathrm{II}}$ pyridine interaction. J. Am. Chem. Soc. 1999, 121, 4296-4297. (1) Sánchez-Molina, I.; Grimm, B.; Krick Calderon, R. M.; Claessens, C. G.; Guldi, D. M.; Torres, T. Self-assembly, host-guest chemistry, and photophysical properties of subphthalocyanine-based metallosupramolecular capsules. J. Am. Chem. Soc. 2013, 135, 1050310511. (m) Nakamura, T.; Ube, H.; Miyake, R.; Shionoya, M. A C $60^{-}$ templated tetrameric porphyrin barrel complex via zinc-mediated selfassembly utilizing labile capping ligands. J. Am. Chem. Soc. 2013, 135, 18790-18793.

(4) (a) AbeyratneKuragama, P. L.; Fronczek, F. R.; Sygula, A. Biscorannulene receptors for fullerenes based on Klarner's tethers: reaching the affinity limits. Org. Lett. 2015, 17, 5292-5295. (b) Atwood, J. L.; Koutsantonis, G. A.; Raston, C. L. Purification of $\mathrm{C}_{60}$ and $\mathrm{C}_{70}$ by selective complexation with calixarenes. Nature 1994, 368, 229-231. (c) Canevet, D.; Pérez, E. M.; Martín, N. Wraparound hosts for fullerenes: tailored macrocycles and cages. Angew. Chem., Int. Ed. 2011, 50, 9248-9259. (d) Kawase, T.; Kurata, H. Ball-, bowl-, and belt-shaped conjugated systems and their complexing abilities: exploration of the concave-convex $\pi-\pi$ interaction. Chem. Rev. 2006, 106, 5250-5273. (e) Yang, Y.; Cheng, K.; Lu, Y.; Ma, D.; Shi, D.; Sun, Y.; Yang, M.; Li, J.; Wei, J. A polyaromatic nano-nest for hosting fullerenes $\mathrm{C}_{60}$ and $\mathrm{C}_{70}$. Org. Lett. 2018, 20, 2138-2142.

(5) (a) Kishi, N.; Li, Z.; Yoza, K.; Akita, M.; Yoshizawa, M. An $\mathrm{M}_{2} \mathrm{~L}_{4}$ molecular capsule with an anthracene shell: encapsulation of large guests up to $1 \mathrm{~nm}$. J. Am. Chem. Soc. 2011, 133, 11438-11441. (b) Kishi, N.; Akita, M.; Yoshizawa, M. Selective host-guest interactions of a transformable coordination capsule/tube with fullerenes. Angew. Chem., Int. Ed. 2014, 53, 3604-3607.

(6) (a) Ronson, T. K.; League, A. B.; Gagliardi, L.; Cramer, C. J.; Nitschke, J. R. Pyrene-edged $\mathrm{Fe}^{\mathrm{II}}{ }_{4} \mathrm{~L}_{6}$ cages adaptively reconfigure during guest binding. J. Am. Chem. Soc. 2014, 136, 15615-15624. (b) Ronson, T. K.; Meng, W.; Nitschke, J. R. Design principles for the optimization of guest binding in aromatic-paneled $\mathrm{Fe}^{\mathrm{II}}{ }_{4} \mathrm{~L}_{6}$ cages. J. Am. Chem. Soc. 2017, 139, 9698-9707.

(7) Meng, W.; Breiner, B.; Rissanen, K.; Thoburn, J. D.; Clegg, J. K.; Nitschke, J. R. A self-assembled $\mathrm{M}_{8} \mathrm{~L}_{6}$ cubic cage that selectively encapsulates large aromatic guests. Angew. Chem., Int. Ed. 2011, 50, $3479-3483$.

(8) (a) Colomban, C.; Szalóki, G.; Allain, M.; Gómez, L.; Goeb, S.; Sallé, M.; Costas, M.; Ribas, X. Reversible $\mathrm{C}_{60}$ ejection from a metallocage through the redox-dependent binding of a competitive guest. Chem. - Eur. J. 2017, 23, 3016-3022. (b) Fuertes-Espinosa, C.; García-Simón, C.; Castro, E.; Costas, M.; Echegoyen, L.; Ribas, X. A copper-based supramolecular nanocapsule that enables straightforward purification of $\mathrm{Sc}_{3} \mathrm{~N}$-based endohedral metallofullerene soots. Chem. - Eur. J. 2017, 23, 3553-3557. (c) García-Simón, C.; GarciaBorràs, M.; Gómez, L.; Parella, T.; Osuna, S.; Juanhuix, J.; Imaz, I.; Maspoch, D.; Costas, M.; Ribas, X. Sponge-like molecular cage for purification of fullerenes. Nat. Commun. 2014, 5, 5557. 
(9) (a) Clever, G. H.; Punt, P. Cation-anion arrangement patterns in self-assembled $\mathrm{Pd}_{2} \mathrm{~L}_{4}$ and $\mathrm{Pd}_{4} \mathrm{~L}_{8}$ coordination cages. Acc. Chem. Res. 2017, 50, 2233-2243. (b) Jansze, S. M.; Wise, M. D.; Vologzhanina, A. V.; Scopelliti, R.; Severin, K. $\mathrm{Pd}_{2}{ }_{2} \mathrm{~L}_{4}$-type coordination cages up to three nanometers in size. Chem. Sci. 2017, 8, 1901-1908. (c) Lewis, J. E. M.; Gavey, E. L.; Cameron, S. A.; Crowley, J. D. Stimuli-responsive $\mathrm{Pd}_{2} \mathrm{~L}_{4}$ metallosupramolecular cages: towards targeted cisplatin drug delivery. Chem. Sci. 2012, 3, 778-784.

(10) (a) Chen, C. F.; Han, Y. Triptycene-derived macrocyclic arenes: from calixarenes to helicarenes. Acc. Chem. Res. 2018, 51, 2093-2106. (b) Mastalerz, M. Porous shape-persistent organic cage compounds of different size, geometry, and function. Acc. Chem. Res. 2018, 51, 2411-2422. (c) Xie, T. Z.; Guo, K.; Guo, Z.; Gao, W. Y.; Wojtas, L.; Ning, G. H.; Huang, M.; Lu, X.; Li, J. Y.; Liao, S. Y.; Chen, Y. S.; Moorefield, C. N.; Saunders, M. J.; Cheng, S. Z.; Wesdemiotis, C.; Newkome, G. R. Precise molecular fission and fusion: quantitative self-assembly and chemistry of a metallo-cuboctahedron. Angew. Chem., Int. Ed. 2015, 54, 9224-9229.

(11) Pullen, S.; Clever, G. H. Mixed-ligand metal-organic frameworks and heteroleptic coordination cages as multifunctional scaffolds-a comparison. Acc. Chem. Res. 2018, 51, 3052-3064.

(12) (a) Cook, T. R.; Stang, P. J. Recent developments in the preparation and chemistry of metallacycles and metallacages via coordination. Chem. Rev. 2015, 115, 7001-7045. (b) Shi, Y.; Sánchez-Molina, I.; Cao, C.; Cook, T. R.; Stang, P. J. Synthesis and photophysical studies of self-assembled multicomponent supramolecular coordination prisms bearing porphyrin faces. Proc. Natl. Acad. Sci. U. S. A. 2014, 111, 9390-9395.

(13) Yazaki, K.; Akita, M.; Prusty, S.; Chand, D. K.; Kikuchi, T.; Sato, H.; Yoshizawa, M. Polyaromatic molecular peanuts. Nat. Commun. 2017, 8, 15914.

(14) Burkhardt, A.; Pakendorf, T.; Reime, B.; Meyer, J.; Fischer, P.; Stube, N.; Panneerselvam, S.; Lorbeer, O.; Stachnik, K.; Warmer, M.; Rodig, P.; Gories, D.; Meents, A. Status of the crystallography beamlines at PETRA III. Eur. Phys. J. Plus 2016, 131, 1-9.

(15) Rogan, Y.; Malpass-Evans, R.; Carta, M.; Lee, M.; Jansen, J. C.; Bernardo, P.; Clarizia, G.; Tocci, E.; Friess, K.; Lanč, M.; McKeown, N. B. A highly permeable polyimide with enhanced selectivity for membrane gas separations. J. Mater. Chem. A 2014, 2, 4874-4877.

(16) (a) Adams, G. B.; O'Keeffe, M.; Ruoff, R. S. Van Der Waals surface areas and volumes of fullerenes. J. Phys. Chem. 1994, 98, 9465-9469. (b) Struch, N.; Bannwarth, C.; Ronson, T. K.; Lorenz, Y.; Mienert, B.; Wagner, N.; Engeser, M.; Bill, E.; Puttreddy, R.; Rissanen, K.; Beck, J.; Grimme, S.; Nitschke, J. R.; Lutzen, A. An octanuclearmetallosupramolecular cage designed to exhibit spincrossover behavior. Angew. Chem., Int. Ed. 2017, 56, 4930-4935.

(17) (a) Liu, Y. M.; Xia, D.; Li, B. W.; Zhang, Q. Y.; Sakurai, T.; Tan, Y. Z.; Seki, S.; Xie, S. Y.; Zheng, L. S. Functional sulfur-doped buckybowls and their concave-convex supramolecular assembly with fullerenes. Angew. Chem., Int. Ed. 2016, 55, 13047-13051. (b) Takeda, M.; Hiroto, S.; Yokoi, H.; Lee, S.; Kim, D.; Shinokubo, H. Azabuckybowl-based molecular tweezers as $\mathrm{C}_{60}$ and $\mathrm{C}_{70}$ receptors. J. Am. Chem. Soc. 2018, 140, 6336-6342. (c) Yokoi, H.; Hiraoka, Y.; Hiroto, S.; Sakamaki, D.; Seki, S.; Shinokubo, H. Nitrogen-embedded buckybowl and its assembly with $\mathrm{C}_{60}$. Nat. Commun. 2015, 6, 8215.

(18) (a) Wood, D. M.; Meng, W.; Ronson, T. K.; Stefankiewicz, A. R.; Sanders, J. K.; Nitschke, J. R. Guest-induced transformation of a porphyrin-edged $\mathrm{Fe}_{4}{ }_{4} \mathrm{~L}_{6}$ capsule into a $\mathrm{Cu}^{\mathrm{I}} \mathrm{Fe}^{\mathrm{II}}{ }_{2} \mathrm{~L}_{4}$ fullerene receptor. Angew. Chem., Int. Ed. 2015, 54, 3988-3992. (b) Schmittel, M.; He, B.; Mal, P. Supramolecular multicomponent self-assembly of shapeadaptive nanoprisms: wrapping up $\mathrm{C}_{60}$ with three porphyrin units. Org. Lett. 2008, 10, 2513-2516.

(19) Zhu, R.; Bloch, W. M.; Holstein, J. J.; Mandal, S.; Schäfer, L. V.; Clever, G. H. Donor-site-directed rational assembly of heteroleptic cis$\left[\mathrm{Pd}_{2} \mathrm{~L}_{2} \mathrm{~L}_{2}^{\prime}\right]$ coordination cages from picolyl ligands. Chem. - Eur. J. 2018, 24, 12976-12982.

(20) Huang, N.; Wang, K.; Drake, H.; Cai, P.; Pang, J.; Li, J.; Che, S.; Huang, L.; Wang, Q.; Zhou, H. C. Tailor-made pyrazolide-based metal-organic frameworks for selective catalysis. J. Am. Chem. Soc. 2018, 140, 6383-6390.

(21) (a) Kräutler, B.; Müller, T.; Duarte-Ruiz, A. Efficient preparation of monoadducts of [60]fullerene and anthracenes by solution chemistry and their thermolytic decomposition in the solid state. Chem. - Eur. J. 2001, 7, 3223-3235. (b) Murata, Y.; Kato, N.; Fujiwara, K.; Komatsu, K. Solid-state $[4+2]$ cycloaddition of fullerene $\mathrm{C}_{60}$ with condensed aromatics using a high-speed vibration milling technique. J. Org. Chem. 1999, 64, 3483-3488. 